\title{
In Vitro Hepatitis B Virus Infection of Human Bone Marrow Cells
}

Jerome B. Zeldis, Hideo Mugishima, Howard N. Steinberg, Emanuel Nir, and Robert Peter Gale

Harvard-Thorndike Laboratory, Harvard Digestive Diseases Center, Charles A. Dana Research Institute, Divisions of Gastroenterology and Hematology/Oncology, Department of Medicine, Beth Israel Hospital and Harvard Medical School, Boston, Massachusetts 02215; Department of Medicine, Division of Hematology and Oncology, University of California at Los Angeles School of Medicine, Los Angeles, California 90024; Laboratory for Blood Morphology and Cytology, Kaplan Hospital, Rehovot, 76100 Israel

\begin{abstract}
Infection of humans with hepatitis B virus (HBV) frequently results in suppression of hematopoiesis; in some cases this may lead to severe bone marrow failure. The mechanism whereby HBV infection affects hematopoiesis is unknown. In vitro exposure of human bone marrow to $\mathrm{HBV}$ results in a dose-dependent inhibition of erythroid (erythroid burst forming units, BFU-E; erythroid colony-forming units CFU-E), myeloid (colony-forming units-granulocyte macrophage CFU-GM), and lymphoid (CFU-[T-lymphocytic]-TL) hematopoietic stem cells. Inactivation or immunoabsorption of $\mathrm{HBV}$ from sera resulted in loss of HBV-induced inhibition of hematopoietic stem cells. De novo gamma interferon was not detectable in the supernatants of cultures of bone marrow cells with HBV. Antibodies to gamma interferon did not affect the suppression of hematopoietic stem cells by HBV. Hepatitis B surface antigen (HBsAg) was detected by immune electron microscopy in nuclei of greater than $70 \%$ of immature hematopoietic cells including myeloblasts, normoblasts, and lymphoblasts; granulocytes had mostly cytoplasmic HBsAg. Hepatitis B virus core antigen ( $\mathrm{HBCAg}$ ) was also detected in about $5 \%$ of $\mathrm{HBV}$ infected bone marrow cells by immunoperoxidase staining. These data indicate that $\mathrm{HBV}$ can infect hematopoietic cells and their progenitors, thus suggesting a wider range of tropism for $\mathrm{HBV}$ than previously reported. These results may provide a basis to study $\mathrm{HBV}$ infection in vitro, and the effects of $\mathrm{HBV}$ on hematopoiesis.
\end{abstract}

\section{Introduction}

Despite the common belief that hepatitis B virus (HBV) ${ }^{1}$ is exclusively hepatotrophic, recent evidence suggests that $\mathrm{HBV}$ can

Portions of this study were presented at the 1st Meeting on Molecular Biology of Hepatitis B Virus, Cold Spring Harbor, NY, 1985; the American Association for the Study of Liver Diseases, Chicago, 1984; 26th Annual Meeting of American Society for Hepatology, Miami, FL, 1984, and were published in abstract form in 1984, Blood. 64:1079; and 1984, Hepatology. 4:1047.

Address reprint requests to Dr. Robert Peter Gale, Department of Medicine/Hematology-Oncology, UCLA Center for Health Sciences, Los Angeles, CA 90024. Dr. Mugishima's current address is Department of Pediatrics, Nihon University School of Medicine, Tokyo, Japan. 1986.

Received for publication 14 August 1985 and in revised form 16 April

1. Abbreviations used in this paper: BFU-E, burst-forming units, erythroid; CFU-E, colony-forming units, erythroid; CFU-GEMM, CFU-

J. Clin. Invest.

(c) The American Society for Clinical Investigation, Inc.

0021-9738/86/08/0411/07 $\$ 1.00$

Volume 78, August 1986, $411-417$ infect human hematopoietic cells. Romet-Lemonne and colleagues found that a small percentage of bone marrow cells from four HBV-infected patients contained hepatitis B virus surface antigen ( $\mathrm{HBsAg})$ and hepatitis $B$ core antigen ( $\mathrm{HBcAg})$. In addition, they established an $\mathrm{HBV}$-containing lymphoblastoid cell line from the bone marrow of a patient with HBV infection (1). Others have identified HBV DNA sequences in the peripheral blood cells of patients with HBV infection $(2,3)$ and in patients with acquired immunodeficiency syndrome (AIDS) (4). Infection of hematopoietic cells by HBV may explain the moderate bone marrow failure as well as the rare cases of aplastic anemia observed in patients with HBV infection (5). To determine the mechanism whereby HBV inhibits normal hematopoiesis, we studied the effect of HBV on the growth of bone marrow progenitor cells in vitro. Normal bone marrow cells (MNC) were exposed to HBV-containing sera and cultured to determine the effect of HBV infection on five classes of hematopoietic stem cells including granulocyte/macrophage (CFU-GM), erythroid (CFU-E, BFU-E), T lymphocyte (CFU-TL), and pluripotent (CFU-GEMM) progenitor cells. Bone marrow cells exposed to HBV were also analyzed by immune electron microscopy for $\mathrm{HBsAg}$ and by immunoperoxidase staining for $\mathrm{HBcAg}$. Our results suggest a direct effect of HBV on human bone marrow progenitor cells and may provide a model for studying HBVinduced bone marrow suppression and $\mathrm{HBV}$ infection of human bone marrow cells.

\section{Methods}

$H B V D N A$. pHBV-1, a gift of Dr. Jesse Summers (Fox Chase Cancer Institute), contains the entire genome of an adw hepatitis $B$ virus inserted in the Eco RI restriction site of PBR322. HBV DNA free of PBR322 vector sequences was purified by preparative electrophoresis of Eco RI digested pHBV-1.

Sera. Serum specimens were obtained from healthy human volunteers with no history of $\mathrm{HBV}$ exposure and who lacked serologic evidence of previous or current HBV infection. HBsAg and HBV DNA positive serum samples were obtained from patients with chronic active hepatitis (3), asymptomatic carrier state (2), and acute hepatitis B (1). HBV DNA negative samples were obtained from patients with non- $A$, non-B chronic active hepatitis (1), acute hepatitis A (1), acute Epstein Barr virus hepatitis (1), hepatocellular carcinoma (1), and $\mathrm{HBsAg}$ positive postnecrotic cirrhosis (1). Sera were filtered with $0.22-\mu \mathrm{m}$ millipore-GU filter unit (Millipore Corp., Bedford, MA) and stored at $-20^{\circ} \mathrm{C}$.

pluripotent cells; CFU-GM, CFU-granulocyte/macrophage; CFU-TL, CFU-T lymphocytic cells; FACS, fluorescent activated cell sorter; FITC, fluorescein isothiocyanate; $\mathrm{HBcAg}$, hepatitis $B$ virus core antigen; $\mathrm{HBs} A g$, Hepatitis B virus surface antigen; $\mathrm{HBV}$, hepatitis B virus; 2ME, 2-mercaptoethanol; MNC, human bone marrow mononuclear cells; PAP, peroxidase antiperoxide; PHA-LCM, phytohemagglutinin-stimulated leukocyte-conditioned medium; SSC, standard saline citrate. 
Bone marrow. Human bone marrow was aspirated from the iliac crest of normal donors for bone marrow transplantation or from ribs obtained at thoracotomy. Informed consent as approved by an Institutional Review Board was obtained from all donors. Bone marrow donors had no serologic evidence of hepatitis or previous HBV infection.

Bone marrow inhibition assay. Bone marrow mononuclear cells. were isolated by Ficoll-Hypaque density centrifugation and suspended in RPMI 1640 supplemented with $10 \%$ heat inactivated $\left(56^{\circ} \mathrm{C}\right.$ for $\left.30 \mathrm{~min}\right)$ fetal calf serum (FCS). $5 \times 10^{6} \mathrm{MNC}$ in $50 \mu \mathrm{l}$ were incubated with $150 \mu \mathrm{l}$ of serial $\log _{10}$ dilutions of human sera at $37^{\circ} \mathrm{C}$ in $5 \% \mathrm{CO}_{2}$ atmosphere for $20 \mathrm{~h}$. The cells were harvested, washed three times, and assayed for CFUGM, CFU-TL, BFU-E, CFU-E, and CFU-GEMM as follows:

$C F U-G M .2 \times 10^{5} \mathrm{MNC}$ were assayed for CFU-GM in minimal essential medium (MEM)-alpha medium (Irvine Scientific, Irvine, CA), containing $0.3 \%$ agar, $20 \% \mathrm{FCS}$, and $10 \%$ phytohemagglutinin-stimulated leukocyte conditioned medium (PHA-LCM). CFU-GM were scored after $10 \mathrm{~d}$ of culture with colonies consisting of greater than 40 cells.

CFU-TL. $1 \times 10^{5} \mathrm{MNC}$ were plated in enriched MEM-alpha medium containing $20 \%$ FCS, $15 \%$ bovine serum albumin (BSA), $5 \times 10^{-5}$ 2-mercaptoethanol (2ME), and $20 \%$ interleukin 2 (6). Colonies were scored after $7 \mathrm{~d}$.

$C F U-E, B F U-E$, and CFU-GEMM. $2 \times 10^{5} \mathrm{MNC}$ were cultured in Iscove's modified Dulbecco's medium in the presence of $0.8 \%$ methylcellulose, 30\% FCS; 10\% PHA-LCM, 1\% deionized BSA (Sigma, St. Louis, MO) $5 \times 10^{-5} 2 \mathrm{ME}$ and $2 \mathrm{U} / \mathrm{ml}$ erythropoietin (Green Cross, Tokyo, Japan) for BFU-E and CFU-GEMM and $0.3 \mathrm{U} / \mathrm{ml}$ erythropoietin for CFU-E. BFU-E and CFU-GEMM were scored after 14 and $16 \mathrm{~d}$ of culture, respectively. CFU-E were scored after $7 \mathrm{~d}$ of culture.

Each assay consisted of $1 \mathrm{ml}$ of the respective mixture plated in duplicate in 35-mm LUX tissue culture dishes (Miles Laboratories, Naperville, IL) and incubated at $37^{\circ} \mathrm{C}$ in $5 \% \mathrm{CO}_{2}$ and $95 \%$ humidity. The number of colonies formed from bone marrow incubated with HBV were compared to that incubated with normal $\mathrm{AB}+$ control serum and the data expressed as percent inhibition. Each assay was run in triplicate and the results are reported as the mean number of colonies for a particular dilution of serum.

\section{Inactivation of $\mathrm{HBV}+$ Sera}

Heat inactivation. $1 \mathrm{ml}$ of sera was incubated in a $100^{\circ} \mathrm{C}$ water bath in an Eppendorf centrifuge tube for $1 \mathrm{~min}$ and then allowed to cool to room temperature.

Urea dialysis. Sera were placed in a dialysis membrane and dialyzed against $4 \mathrm{M}$ urea or phosphate-buffered saline (PBS) for $48 \mathrm{~h}$ with two changes of dialysate, and then against three changes of PBS.

Immunoabsorption of $\mathrm{HBSAg}$ and $\mathrm{HBV} D N A$. The $\mathrm{HBsAg}+\mathrm{HBV}$ DNA+ serum was repeatedly immunoabsorbed to a mouse monoclonal anti-HBs Sepharose column until $>95 \%$ of the HBsAg was removed from the eluate as judged by endpoint titration of serial dilutions in an immunoassay for HBsAg. The serum eluate was concentrated to the original volume and sterilized by $0.22 \mu \mathrm{m}$ filtration. The column was washed with 10 vol of PBS and eluted with a pH 2.4 glycine-HCl buffer. The eluate was neutralized, dialyzed against PBS, and concentrated to the original volume. The immunoabsorbed serum was demonstrated to have no HBV DNA by dot-blot analysis and $<95 \%$ of initial $\mathrm{HBsAg}$ concentration. In contrast, the eluate had both HBsAg and HBV DNA. The mouse monoclonal anti-HBs Sepharose column was the gift of Dr. Jack Wands.

Absorption of sera with bone marrow cells. $5 \times 10^{5} \mathrm{MNC}$ in RPMI 1640 were incubated with an equal volume of sera for $2 \mathrm{~h}$ at $4^{\circ} \mathrm{C}$. The cells were pelleted at $400 \mathrm{~g}$ and the supernatant removed.

Monoclonal anti-gamma interferon antibodies. Monoclonal antigamma interferon antibodies with a neutralizing effect of 1,600 nU/unit gamma interferon were obtained from Dr. Jan T. Vilcek (7). Bone marrow cells were incubated with $\mathrm{HBV}+$ serum and a volume of antibody capable of neutralizing $40 \mathrm{U} / \mathrm{ml}$ of gamma interferon. After $20 \mathrm{~h}$ of incubation, the MNC were washed twice and assayed for CFU-E and CFU-GM as described.

\section{HBV DNA assay}

The sensitivity of this assay is $2.8 \times 10^{4} \mathrm{HBV}$ DNA molecules per $50 \mu \mathrm{l}$ serum. The preparation of the serum samples was performed as described (8), Biodyne Nylon Membrane (Pall-Ultra Fine Corp, Glen Cove, NY) was used instead of nitrocellulose. The membranes were prehybridized and hybridized to ${ }^{32}$ P-labeled HBV DNA by standard techniques (9). The filters were washed at room temperature with $2 \times$ standard saline citrate (SSC) $(1 \times \mathrm{SSC}=0.15 \mathrm{M} \mathrm{NaCl}, 0.015 \mathrm{M}$ sodium citrate $\mathrm{pH} 7.0)$ with $0.5 \%$ SDS for $5 \mathrm{~min}$, then $2 \times$ SSC with $0.1 \%$ sodium dodecyl sulfate (SDS) for $15 \mathrm{~min}$, then twice in $0.1 \times$ SSC with $0.5 \%$ SDS at $68^{\circ} \mathrm{C}$ for $1 \mathrm{~h}$ each. The filters were air-dried and autoradiographed overnight and for $7 \mathrm{~d}$ at $-70^{\circ} \mathrm{C}$ using Kodak X-Omat XAR film (Eastman Kodak Co., Rochester, NY) and a Cronex Lightning-Plus enhancing screen (DuPont, Wilmington, DE). ${ }^{32}$ P-labeled HBV were produced by nick translation using standard techniques (9). The ${ }^{32} \mathrm{P}$-labeled HBV DNA probe (sp act $1-4 \times 10^{8} \mathrm{cpm} / \mu \mathrm{g}$ DNA) did not cross hybridize with pBR322 DNA.

\section{Fluorescent activated cell sorter (FACS) analysis of human} bone marrow cells

After $20 \mathrm{~h}$ incubation with HBV or control serum, $1 \times 10^{6} \mathrm{MNC}$ were washed twice with $0.1 \%$ sodium azide $\left(\mathrm{NaN}_{2}\right)$; then incubated with 200 $\mu l$ of murine monoclonal anti-HBs antibody (1:100) or an identical class of murine hybridoma protein $(5 \mu \mathrm{g})$ without anti-HBs activity for 45 min at $24^{\circ} \mathrm{C}$; then washed with $\mathrm{PBS}$ with $\mathrm{NaN}_{2} .200 \mu \mathrm{l}$ of fluorescene isothiocyanate (FITC)-conjugated goat antimouse IgG antibody (Tago, Burlingame, CA) was added and the cells incubated at $4^{\circ} \mathrm{C}$ for $45 \mathrm{~min}$. Cells were washed and resuspended in $1 \mathrm{ml}$ of PBS with $\mathrm{NaN}_{2}$. Samples were examined with FACS (Cytofluorograf 504, Ortho, Raritan, NJ). The murine monoclonal antibodies were the gift of Dr. Jack Wands.

\section{Immune electromicroscopy of $M N C$}

$1 \times 10^{7}$ bone marrow cells were incubated for $20 \mathrm{~h}$ with sera as described above. Samples were washed twice with RPMI 1640 medium and incubated with murine monoclonal anti-HBs (diluted 1:100) for $45 \mathrm{~min}$. Cells were washed and fixed for 10 min with Karnovsky fixative (10) and analyzed. For surface labeling, cells were washed and incubated for $1 \mathrm{~h}$ with $150 \mu \mathrm{l}$ of goat antimouse immunoglobulin linked to colloidal gold particles (size $\pm 20 \mathrm{~nm}$ ) (GAMG 20 Janssen Pharmaceutia N.V.B2340, Beerse-Belgium, diluted 1:1), washed and refixed for $24 \mathrm{~h}$ or more prior to myeloperoxidase staining (11). For intracellular labeling, cells were treated with Karnovsky fixative for $24 \mathrm{~h}$ and embedded. Ultra-thin sections were labeled with GAMG-20 for $15 \mathrm{~min}$ and stained with uranyl acetate.

Preparations were examined with an electron microscope. Black grains appeared in cells containing $\mathrm{HBsAg}$.

\section{Immunoperoxidase detection of $\mathrm{HBCAg}$}

$1 \times 10^{6} \mathrm{MNC}$ were incubated with sera as described above and then transferred to a microscope slide using a cytospin (Shandon-Southern, England). The cells were then stained for $\mathrm{HBcAg}$ by the protocol and reagents of the DAKO peroxidase antiperoxide (PAP) kit for $\mathrm{HBcAg}$ (DAKO Corp., Santa Barbara, CA) (12). Samples were air-dried, incubated with $3 \% \mathrm{H}_{2} \mathrm{O}_{2}$ in methanol for $5 \mathrm{~min}$ to inactivate endogenous peroxidase. Slides were rinsed with $0.05 \mathrm{M}$ Tris buffer (pH 7.6) and incubated with rabbit anti-HBc or nonimmune rabbit serum for $20 \mathrm{~min}$. Cells were washed again with Tris buffer and incubated with a swine antirabbit immunoglobulin for $20 \mathrm{~min}$, rinsed, and incubated with soluble horseradish peroxidase rabbit anti-horseradish peroxidase complex for $20 \mathrm{~min}$. Samples were incubated with the peroxidase substrate containing 3-amino-9-ethylcarbazole, $0.1 \mathrm{M}$ acetate buffer and $0.3 \% \mathrm{H}_{2} \mathrm{O}_{2}$ before counterstaining with hematoxylin to demonstrate nuclei.

\section{Results}

Co-culture of human bone marrow mononuclear cells (MNC) with $\mathrm{HBV}$ containing sera resulted in a dose-dependent inhi- 
bition of the five types of stem cells studied. For example, exposure of bone marrow cells to an undiluted HBV DNA positive serum resulted in suppression of CFU-GM, BFU-E, and CFUTL colony formation by $65 \pm 3,46 \pm 6$, and $49 \pm 3 \%$, respectively, compared with controls (Fig. 1). Although the absolute number of colonies in each assay varied for different bone marrow specimens, percent inhibition was internally consistent for each experiment. Incubation of bone marrow cells with serial $\log _{10}$ dilutions of HBV containing sera resulted in the gradual loss of the HBV-mediated suppression. Inhibition of CFU-GM and CFU-TL was still observed using sera diluted 1:100. Other sera that had higher concentrations of HBV DNA inhibited the number of CFU-GM and BFU-E by as much as $100 \%$ compared to control (data not shown). CFU-E was also inhibited by HBV DNA+ sera. Undiluted HBV DNA+ sera from three patients inhibited CFU-E by $38 \pm 7,72 \pm 3$, and $100 \pm 0 \%$. In a preliminary study, CFU-GEMM was also found to be inhibited by $75 \%$ of control by undiluted HBV serum. (Exposure to control serum gave $8 \pm 2$ colonies per $2 \times 10^{5} \mathrm{MNC}$, while undiluted $\mathrm{HBV}$ sera produced $2 \pm 1$ CFU-GEMM per $2 \times 10^{5} \mathrm{MNC}$.)

The effect of preincubation time on subsequent BFU-E colony formation by two different HBV DNA containing sera is illustrated in Fig. 2. Although no inhibition of BFU-E was observed after $3 \mathrm{~h}$ of preincubation with undiluted serum 1, complete suppression was seen after $20 \mathrm{~h}$ preincubation of undiluted serum but not serum diluted 1:100. Serum 2, which contained a tenfold higher concentration of HBV DNA, completely inhibited BFU-E after $3 \mathrm{~h}$ incubation when undiluted, but not at a 1:1,000 dilution. Similar results were obtained with CFU-GM and CFU-E.

Nine HBV DNA negative sera from patients with chronic non-A, non-B hepatitis, hepatitis A, Epstein-Barr virus-related hepatitis, hepatoma and healthy normal volunteers had no significant effect on hematopoietic stem cells ( $<20 \%$ inhibition). In these experiments, significant inhibition of CFU-GM assay by $>30 \%$ correlated with the presence in serum of HBV DNA sequences. CFU-GM were inhibited by all HBV DNA positive sera whether or not circulating mononuclear cells from the patient contained HBV DNA (Table I).

To determine if the $\mathrm{HBV}$ virion is responsible for inhibition of CFU-GM, HBV DNA positive sera were treated to inactivate

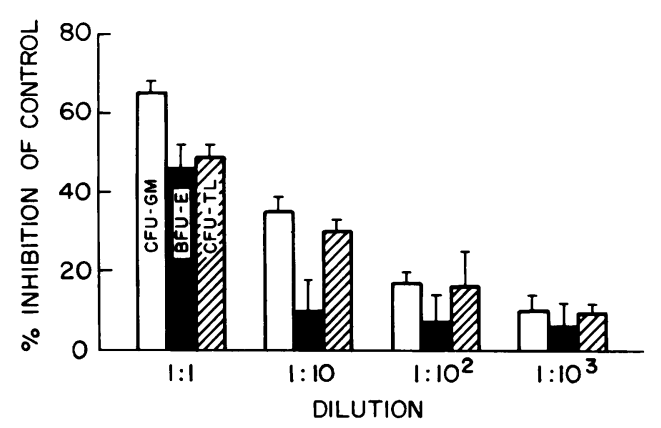

Figure 1. Effect on hematopoietic colony formation of incubating MNC with serum containing HBV DNA. The data charted are the mean inhibitions and SEM of colony formation produced by exposure to a HBV DNA+ serum compared to the number of colonies of a negative control serum (see Methods). The serial $\log _{10}$ dilutions of sera were made in RPMI 1640 media. The number of colonies for the control serum for CFU-GM was $224 \pm 8(95 \% \mathrm{CI})$ per $10^{5}$ cells; for BFUE, $230 \pm 4$; and for CFU-TL, $1,228 \pm 41$.

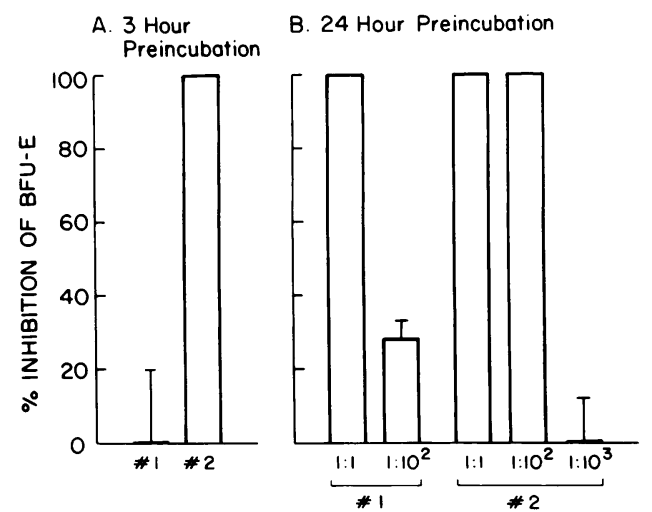

Figure 2. The effect of two HBV DNA+ sera on BFU-E after a 3- and 24-h preincubation. $\mathrm{MNC}$ were incubated with $\mathrm{AB}+$ control serum or HBV DNA + sera for 3 or $24 \mathrm{~h}$; washed four times and plated into the BFU-E assay as described in the methods. Plotted are the mean values of three simultaneous determinations and the SEM. The sera used in the $3 \mathrm{~h}$ incubation were diluted $1: 1$. The mean colony number and the $95 \% \mathrm{CI}$ for the 3 -h control was $13.9 \pm 3.2$ per $10^{5}$ cells and for the $24-\mathrm{h}$ control, 58.6 \pm 13.4 .

or remove infectious HBV by three techniques: $(a)$ heat $(1 \mathrm{~min}$ at $\left.98^{\circ} \mathrm{C}\right) ;(b)$ dialysis against $4 \mathrm{M}$ urea; and $(c)$ removal of $\mathrm{HBV}$ using a mouse monoclonal anti-HBs affinity column. The effect of these treatments on HBV mediated suppression of CFU-GM are shown in Fig. 3. Both heat inactivation and urea dialysis, which eliminate infectivity of $\mathrm{HBV}$, removed the inhibitory effect

Table I. Inhibition of CFU-GM by Sera

\begin{tabular}{cllll}
\hline & & \multicolumn{2}{l}{ HBV DNA in } & \\
\cline { 3 - 4 } Patient & Diagnosis & Serum* & $\begin{array}{l}\text { Mononuclear } \\
\text { cells+ }\end{array}$ & $\begin{array}{l}\text { Inhibition of } \\
\text { CFU-GM } \neq\end{array}$ \\
\hline & & & & $\%$ \\
1 & HBV CAH & + & + & $37 \pm 6$ \\
2 & HBV CAH & + & + & $37 \pm 6$ \\
3 & HBV CAH & + & - & $71 \pm 3$ \\
4 & HBV Carrier & + & - & $37 \pm 10$ \\
5 & HBV Carrier & + & - & $40 \pm 6$ \\
6 & HBV Carrier & + & - & $30 \pm 5$ \\
7 & HCC/HBsAg- & - & - & $17 \pm 7$ \\
8 & NANB CAH & - & - & $7 \pm 6$ \\
9 & HAV Hepatitis & - & - & $2 \pm 7$ \\
10 & EBV Hepatitis & - & - & $10 \pm 6$ \\
11 & Cirrhosis/HBsAg+ & - & ND & $15 \pm 7$ \\
& & & & \\
\hline
\end{tabular}

* HBV DNA determined from $50 \mu$ l of sera by a dot blot technique described in Methods. +, HBV DNA positive; -, no detectable HBV DNA after $7 \mathrm{~d}$ autography. +HBV DNA was assayed by extracting DNA from mononuclear fraction of a Ficoll-Hypaque fraction of peripheral blood; shearing the DNA, electrophoresing the DNA in $0.7 \%$ agarose, Southern blotting to nitrocellulose (NC) and exposing the $\mathrm{NC}$ filter to radioactive HBV DNA probes (2).

$\ddagger$ Inhibition of $<20 \%$ was considered not statistically significant. Each value is the mean of three measurements with the same undiluted serum. Listed are the percentage inhibition and the standard error of the mean. The control serum produced $157 \pm 5.6$ colonies per $2 \times 10^{5}$ cells. 


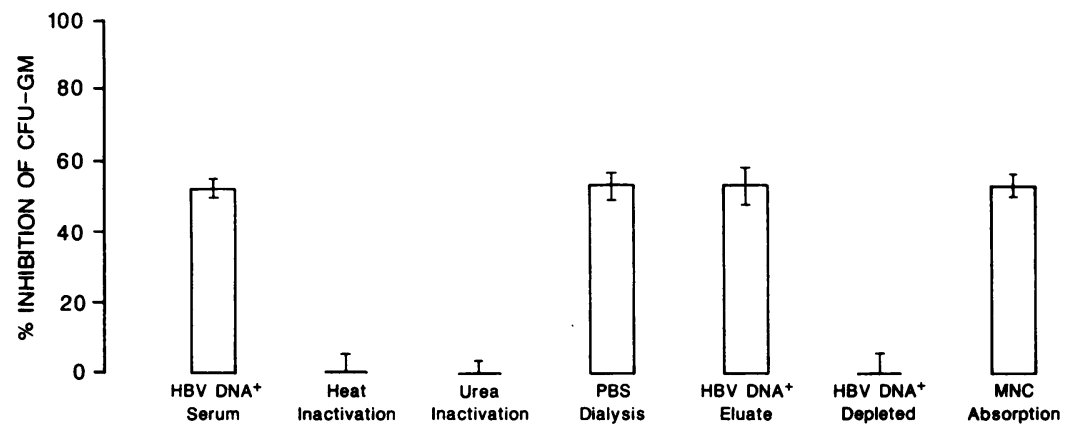

Figure 3. Percent inhibition of CFU-GM by treating a serum with heat, urea dialysis, and immunoabsorption. This serum was treated by several techniques described in Methods. After each treatment, the serum was assayed for its effect on the CFU-GM. "HBV DNA+ serum" refers to an untreated HBV DNA+ serum obtained from a patient with chronic active hepatitis. This serum was heat inactivated, dialyzed against $4 \mathrm{M}$ urea (urea dialysis) or PBS (PBS dialysis); immunoabsorbed (HBV DNA+ depleted), immunopurified (HBV DNA+ eluted), and preabsorbed against MNC (MNC absorption). The results shown are the percent inhibition \pm SEM of CFU-GM produced by 1:1 dilution of the samples. The control serum produced $205 \pm 14(95 \% \mathrm{CI})$ colonies per $2 \times 10^{5} \mathrm{MNC}$.

of HBV DNA positive sera on CFU-GM. In contrast, dialysis of HBV DNA+ sera against PBS did not suppress CFU-GM. Serum depleted of HBV DNA following passage through an anti-HBs immunoabsorption column no longer inhibited CFUGM. The HBV DNA containing eluate recovered from the column markedly suppressed CFU-GM. The inhibitory activity of HBV containing sera thus coincided with HBV infectivity and the presence of $\mathrm{HBs} \mathrm{Ag}$ immunoreactivity and of HBV DNA.

To investigate whether antibodies to HLA might account for inhibition of CFU-GM, HBV DNA+ serum was absorbed against bone marrow cells from the same donor used in the stem cell assays. Preabsorption did not abrogate the inhibitory effect of HBV DNA+ serum on CFU-GM. Additional evidence against a role of anti-HLA antibodies is the finding that the same serum inhibited progenitors from individuals of different HLA types and that different HBV DNA+ sera inhibited bone marrow from a single donor. As indicated, HBV DNA - sera from individuals had no effect on CFU-GM.

Gamma interferon can inhibit CFU-GM in vitro (13) and may play a role in the suppression of hematopoiesis in some cases of aplastic anemia $(14,15)$. The HBV DNA+ sera we studied typically contained 5-15 U/ml of gamma interferon vs. $5 \mathrm{U} / \mathrm{ml}$ in normal sera (as determined by the VSV/WISH assay [16]). It was therefore necessary to determine whether the observed inhibition of bone marrow progenitor cells with $\mathrm{HBV}$ DNA+ sera was mediated by gamma interferon. Incubation of HBV DNA+ serum with a monoclonal anti-gamma interferon antibody prior to addition of bone marrow cells did not affect the serum's ability to inhibit CFU-GM or CFU-E colony formation (Fig. 4). Furthermore, preincubation of bone marrow cells with 10 to $1,000 \mathrm{U} / \mathrm{ml}$ gamma interferon for $20 \mathrm{~h}$ did not alter the number of CFU-GM (data not shown). Finally, the concentration of gamma interferon recovered from these cultures decreased with incubation time consistent with the conclusion that gamma interferon was not induced during culture of bone marrow cells with $\mathrm{HBV}$.

Having established that HBV can inhibit hematopoiesis in vitro, we next determined if $\mathrm{HBV}$-associated antigens could be detected in bone marrow cells exposed to HBV containing sera. Bone marrow was incubated with HBV DNA+ sera, washed, incubated with murine anti-HBs antibodies or hyperimmune anti-HBs sera, and examined for indirect immunofluorescence by fluorescence microscopy or using a FACS. $1-2 \%$ of MNC co-cultured with HBV containing sera exhibited surface fluorescence for $\mathrm{HBsAg}$ by indirect immunofluorescence; cells either incubated with normal control sera or stored with sera without
anti-HBs activity were negative. FACS analysis indicated that the HBV-infected bone marrow cells incubated with anti-HBs murine monoclonal antibodies contained a substantial population (5\%) of brightly fluorescent positive cells. Only MNC incubated with HBV-containing sera and stained with anti-HBs monoclonal antibody exhibited fluorescence in a size population of cells consistent with hematopoietic cells. No fluorescence was observed either in MNC incubated with HBV DNA- AB serum and stained with anti-HBs or in MNC incubated with HBV DNA+ sera and stained with control monoclonal antibody with no anti-HBs activity.

To better define the population of MNC containing viral antigens, immunoelectron microscopic analyses of bone marrow cells cultured with and without HBV DNA+ serum were performed. Surface labeling with murine monoclonal anti-HBs antibodies was only observed in $<10 \%$ of the myeloperoxidasepositive myeloblasts and myelocytes. Lymphocytes and erythrocyte precursors did not have $\mathrm{HBsAg}$ on their surface. In contrast, intracellular labeling with monoclonal anti-HBs antibodies was detected in nuclei and cytoplasm of all nucleated cells examined. The labeling pattern of the nucleus and cytoplasm was different among the various hematopoietic cell types (Table II). Greater than $70 \%$ of nuclei of myeloblasts, normoblasts, and lymphocytes were $\mathrm{HBsAg+}$; granulocytes contained predomi-

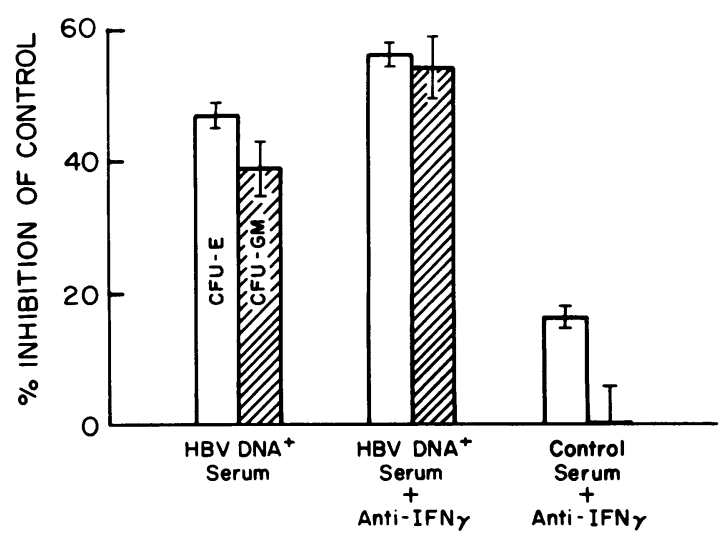

Figure 4. Monoclonal anti-gamma interferon antibodies do not inhibit the HBV DNA+ serum's suppression of CFU-E and CFU-GM. An excess of monoclonal anti-gamma interferon antibody (Anti-INF $\gamma$ ) was incubated with MNC and HBV as described in Methods. The mean number of colonies of the control were $456 \pm(95 \% \mathrm{CI})$ for CFU$\mathrm{E}$ and $47 \pm 3(95 \% \mathrm{CI})$ for CFU-GM. 
Table II. Distribution of HBsAg in Cytoplasm and Nucleus of Different Hemopoietic Cells as Determined by a Gold Label*

\begin{tabular}{lll}
\hline Cell & Cytoplasm labeling & Nuclear labeling \\
\hline & $\%$ & $\%$ \\
Myeloblasts & 20 & 80 \\
Promyelocytes and myelocytes & 50 & 50 \\
Metamyelocytes & 55 & 45 \\
Granulocytes & 76 & 24 \\
Normoblasts & 30 & 70 \\
Lymphocytes & 15 & 85 \\
Red blood cells & 0 & 0
\end{tabular}

* MNC incubated with control sera instead of HBV DNA+ sera did not have two or more gold particle clusters. Data are expressed as the percentage of 50 cells of each type of bone marrow cell that contained clusters of gold particles.

nantly cytoplasmic HBsAg. Mature erythrocytes which lack nuclei, contained no HBsAg. Fig. 5 illustrates cytoplasmic and nuclear HBsAg detected by immunoelectron microscopy. Although the density of $\mathrm{HBsAg}$ detected in the MNC was low, results were reproducible. Furthermore, MNC preincubated with sera from healthy controls or MNC incubated with a control murine myeloma protein were negative. Intracellular inclusions resembling virions or core particles were not seen on electronmicroscopy of MNC incubated for $24 \mathrm{~h}$ with $\mathrm{HBV}$.
Bone marrow cells incubated with HBV DNA+ sera were assayed for $\mathrm{HBcAg}$ by the PAP technique. $\mathrm{HBcAg}$ was detected in MNC incubated with $\mathrm{HBV}+$ sera but not in controls. About $5 \%$ of cells stained positive for $\mathrm{HBcAg}$.

\section{Discussion}

HBV infections are associated with mild suppression of hematopoiesis and rarely with cases of severe aplastic anemia. Our investigations of the in vitro effects of $\mathrm{HBV}$ on colony formation may provide a model to investigate these phenomena. Our studies indicate that suppression of hematopoiesis in vitro is directly related to an effect of $\mathrm{HBV}$ on hematopoietic progenitor cells. Exposure of bone marrow cells to HBV DNA + sera results in the in vitro suppression of erythroid (CFU-E; BFU-E), myeloid (CFU-GM), and lymphoid (CFU-TL). Preliminary data also suggest an effect on pluripotential (CFU-GEMM) stem cell growth. Viral inactivation studies (Fig. 3) and serial dilution of HBV DNA+ sera suggest that the inhibitory effect of $\mathrm{HBV}$ is mediated by infectious virions ("Dane particles"). Sera that lacked HBV DNA but contained HBsAg, corresponding to the noninfectious "22-nm particles" and "pencil shapes," had no effect on bone marrow progenitors. Inactivation of HBV DNA+ sera by heat or $4 \mathrm{M}$ urea treatment that eliminate the infectivity but not the immunogenicity of $\mathrm{HBV}$, resulted in the loss of CFU-GM inhibition. Removal of viral particles by immunoabsorption using an anti-HBs column similarly eliminated CFUGM inhibition. Exposure of HBV DNA+ serum to anti-gamma interferon antibodies did not alter inhibition of CFU-E and CFU-
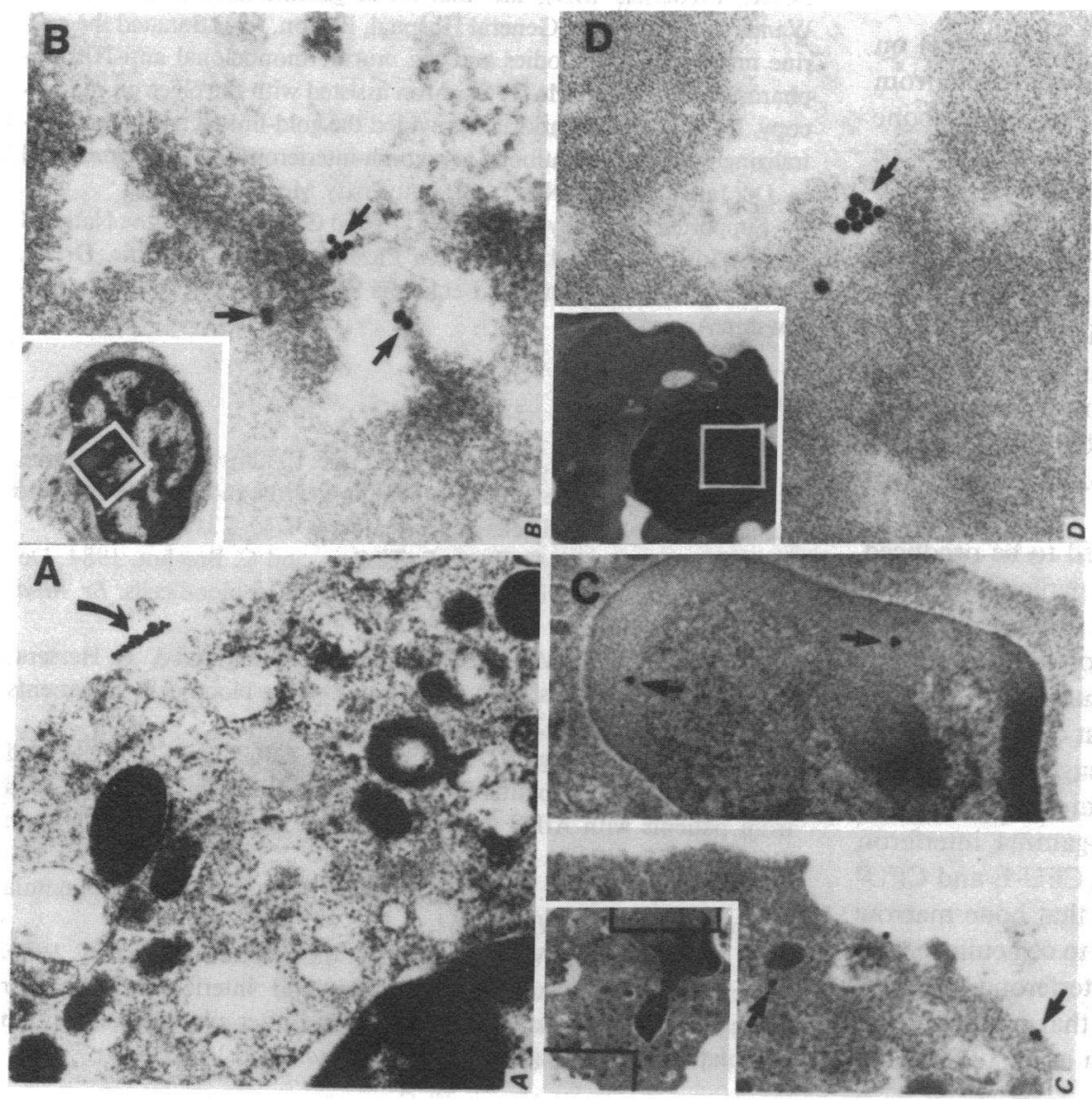

Figure 5. Immune electron microscopy of bone marrow mononuclear cells incubated with HBV DNA+ serum. (A) Myeloperoxidase positive myelocyte with gold particles on the surface $(\times 4,500) ;(B)$ Myeloblast with nuclear labeling $(\times 14,000) ;(C)$ Neutrophil with both cytoplasmic and nuclear labeling $(\times 4,500)$; and (D) normoblast with nuclear labeling $(\times 20,000)$. Only MNC incubated with HBV and stained with murine monoclonal anti-HBs antibodies had clusters of two or more gold particles. MNC incubated with $\mathrm{HBV}$ and stained with nonspecific monoclonal antibody or MNC incubated with control sera and stained with monoclonal anti-HBs antibodies did not have clusters of gold particles. 
GM, suggesting that gamma interferon does not play a role in this process. These results are consistent with the hypothesis of a direct effect of $\mathrm{HBV}$ on hematopoietic stem cells.

Demonstration of both $\mathrm{HBsAg}$ and $\mathrm{HBcAg}$ in the cytoplasm and nucleus of mature and immature bone marrow mononuclear cells is consistent with the hypothesis that the virus is able to infect hematopoietic cells. FACS analysis demonstrated that $\sim 5 \%$ of MNC have HBsAg on their surface. This may be due to HBV binding to receptors on the hematopoietic cells. Whether there is viral replication or active transcription in these cells is unknown but is presently under study. The absence of intracellular virus and core particles on electron microscopy makes it unlikely that active viral production was completed during the 20-h incubation of bone marrow cells with HBV. Recent work with the duck hepatitis virus, another hepadna virus, indicated that at least $6 \mathrm{~d}$ are needed before viral assembly occurs. These studies and other recently reported investigations extend the range of tropism of $\mathrm{HBV}$ in man $(1-3,17,18)$. Recently, Laure et al. (4) demonstrated that $T$ cell clones derived from AIDS patients contain HBV DNA.

In addition to $\mathrm{HBV}$, other types of acute viral infections, including non-A, non-B hepatitis, hepatitis A, and Epstein-Barr virus hepatitis are associated with bone marrow suppression. However, sera from patients with these infections have no effect on bone marrow progenitor cells. Their inability to suppress bone marrow progenitor cells may be related to the presence of low concentrations of virus. Indeed, it has been shown that during the clinical phase of acute hepatitis A infection, the serum concentration of virus is very low. The lack of an inhibitory effect by sera of patients with other infectious agents may be analogous to the gradual loss of inhibition observed with the serial dilution of HBV DNA+ sera.

In their study of a parvovirus-like agent and its effect on hematopoiesis, Young et al. reported that acute phase sera from patients with $\mathrm{HBV}$-associated hepatitis failed to inhibit bone marrow progenitor cells in vitro (19). This lack of effect may be attributed to the exposure of bone marrow cells only to a 1:100 dilution of sera. As demonstrated in Figs. 1 and 2, the inhibitory effect of HBV on hematopoiesis may be readily diluted out at a 1:100 concentration of sera containing only a moderate amount of HBV DNA. Sera that contain the parvovirus-like agent described by Young et al. (19) inhibit CFU-E at greater dilutions than sera that contain HBV. The greater potency of the parvovirus-like agent containing sera may be a reflection of a higher concentration of active virus in serum as compared to that of $\mathrm{HBV}$.

Gamma interferon has been demonstrated to be produced by the peripheral blood mononuclear cells of patients who have aplastic anemia. Some patients with aplastic anemia also have very high concentrations of gamma interferon in their serum. This has led to the hypothesis that gamma interferon may be a mediator of the hematopoietic suppression that occurs in aplastic anemia $(14,15)$. However, our results suggest that HBV suppression of colony formation is not mediated by gamma interferon. The addition of monoclonal anti-gamma interferon antibody did not affect HBV suppression of CFU-E and CFUGM. It should be emphasized furthermore, that bone marrow cells were preincubated with HBV sera prior to cell culture, and thus only exposed to low levels of gamma interferon (10-20 U/ $\mathrm{ml}$ ) for 18 to $24 \mathrm{~h}$. We have demonstrated that preincubation of bone marrow cells with gamma interferon up to $1,000 \mathrm{U} / \mathrm{ml}$ did not affect colony formation. These results are similar to those reported by Toretsky et al. (20) who showed that transient exposure to bone marrow cells to gamma interferon did not significantly suppress colony formation. A dose-dependent suppression of colony formation was only observed when gamma interferon was added in continuous culture to bone marrow cells (unpublished observations, 13, 15, 20).

Though both alpha and gamma interferon are induced by acute viral infections, a putative role for alpha interferon in $\mathrm{HBV}$ suppression of hemopoiesis was not studied. It should be noted that the dose-response suppression of colony formation by alpha interferon is similar to gamma interferon for CFU-GEMM, BFUE, and day 7 CFU-GM. Day 14 CFU-GM, which were assayed in the present study, were significantly less sensitive to alpha interferon (13). Thus, while alpha interferon's role in the suppression of hematopoiesis observed by HBV in vitro cannot be excluded, it is unlikely.

Since hematopoietic cells are easily obtained, and because there are extensive in vivo and in vitro data regarding their growth, progenitor-progeny relationships, and growth-factor requirements, the effects of $\mathrm{HBV}$ on bone marrow progenitor cells can be readily studied in vitro. To date, there is no in vitro model to examine HBV infection of human hepatocytes and hepatoma cells. The infection of human bone marrow cells with HBV thus may provide a model to study the cellular and molecular events associated with $\mathrm{HBV}$ infection.

\section{Acknowledgments}

Dr. Susan Wormsley (Cytokinetics, La Jolla, CA), performed the cytofluorographic analyses; Dr. Annette Maluish (National Cancer Institute/ FCRC, Frederick, MD), the analysis of gamma-interferon; Dr. Jack Wands (Massachusetts General Hospital, Boston, MA) donated the murine monoclonal antibodies and the murine monoclonal anti-HBs Sepharose column; and Mr. T. Shimron assisted with the electron microscopy. Dr. Robertson Parkman provided the gold-linked antibody. Neutralizing monoclonal antibody to gamma-interferon was kindly provided by Dr. Jan T. Vilcek (New York University Medical Center).

Supported in part by grant CA23175 and CA33012 from the National Cancer Institute. Dr. J. Zeldis is a Pfizer postdoctoral fellow. Dr. H. Steinberg is the recipient of a Leukemia Society of America Special Fellowship Award.

\section{References}

1. Romet-Lemonne, J. L., M. F. McLane, E. Elfassi, W. A. Haseltine, J. Azocar, and M. Essex. 1983. Hepatitis B virus infection in cultured human lymphoblastoid cells. Science (Wash. DC). 221:667-669.

2. Pontisso, P., M. C. Poon, P. Tiollais, and C. Brechot. 1984. Detection of hepatitis B virus DNA in mononuclear blood cells. Br. Med. J. 288:1563-1566.

3. Lie-Injo, L. E., M. Balasagaram, C. G. Lopez, and A. R. Herrera. 1983. Hepatitis B virus DNA in liver and white blood cells of patients with hepatoma. DNA. 2:301-308.

4. Laure, F., D. Zagury, A. G. Saimot, R. C. Gallo, B. H. Hahn, and C. Brechot. 1985. Hepatitis B virus DNA sequence in lymphoid cells from patients with AIDS and AIDS-related complex. Science (Wash. DC). 229:561-563.

5. Zeldis, J. B., J. L. Dienstag, and R. P. Gale. 1984. Aplastic anemia and hepatitis. Am. J Med. 74:64.

6. Kermani-Arab, V., K. Hirji, A. R. Ahmed, and J. L. Fahey. 1984. Deficiency of interleukin-2 production and interleukin-2 receptor expression on peripheral blood leukocytes after phytohemagglutinin stimulation in pemphigus. J. Invest. Dermatol. 83:101-104. 
7. Rigby, W. F. C., E. D. Ball, P. M. Buyre, and M. W. Fanger. 1985. The effects of recombinant-DNA-derived interferons on the growth of myeloid progenitor cells. Blood. 65:858-861.

8. Scotto, J., M. Hadchovel, C. Hery, J. Yuart, P. Tiollais, and C. Brechot. 1983. Detection of hepatitis B virus DNA in serum by simple spot hybridization technique: Comparison with results for other viral markers. Hepatology. 3:L279-284.

9. Maniatis, T., E. F. Fritsch, and J. Sambrook. 1982. Molecular cloning: A laboratory manual. Cold Spring Harbor Laboratory, Cold Spring Harbor, NY.

10. Karnovsky, M. J. 1965. A formaldehyde-glutaraldehyde fixative of high osmolality for use in electron microscopy. J. Cell Biol. 27:137A.

11. Graham, R. C., Jr., and M. J. Karnovsky. 1966. The early stages of absorption of injected horseradish peroxidase in the proximal tubules of mouse kidney: ultrastructural cytochemistry by a new technique. $J$. Histochem. Cytochem. 14:291-302.

12. Sternberger, L. A., P. H. Hardy, Jr., J. J. Cuculis, and H. G. Meyer. 1970. The unlabeled antibody enzyme method of immunohistochemistry: preparation and properties of soluble antigen-antibody complex (horseradish peroxidase-antihorseradish peroxidase) and its use in identification of spirochetes. J. Histochem. Cytochem. 18:315-333.

13. Broxmeyer, H. E., L. I. Lu, E. Platzer, C. Feit, L. Juliano, and B. Y. Rubin. 1983. Comparative analysis of the influences of human gamma, alpha and beta interferons on human multipotential (CFU-
GEMM), erythroid (BFU-E) and granulocyte-macrophage (CFU-GM) progenitor cells. J. Immunol. 131:1300-1305.

14. Zoumbos, N. C., P. Gascon, J. Y. Djeu, and N. S. Young. 1985. Interferon is a mediator of hematopoietic suppression in aplastic anemia in vitro and possibly in vivo. Proc. Natl. Acad. Sci. USA. 82:188-192.

15. Zoumbos, N. C., J. Y. Djeu, and N. S. Young. 1984. Interferon is the suppressor of hematopoiesis generated by stimulated lymphocytes in vitro. J. Immunol. 133:769-774.

16. Djeu, J., N. Stocks, K. Zoon, G. J. Stanton, T. Timonen, and R. B. Herberman. 1982. Positive self regulation of cytotoxicity in human natural killer cells by production of interferon upon exposure to influenza and herpes viruses. J. Exp. Med. 156:1222-1234.

17. Blum, H. E., A. T. Haase, and G. N. Vyas. 1984. Molecular pathogenesis of hepatitis B virus infection: simultaneous detection of viral DNA and antigens in paraffin-embedded liver sections. Lancet. ii: 771-775.

18. Blum, H. E., L. Stowring, A. Figus, C. K. Montgomery, A. T. Haase, and G. N. Vyas. 1983. Detection of hepatitis B virus DNA in hepatocytes, bile duct, epithelium, and vascular elements by in situ hybridization. Proc. Natl. Acad. Sci. USA. 80:6685-6688.

19. Young, N. S., P. P. Mortimer, J. G. Moore, and R. K. Humphries. 1984. Characterization of a virus that causes transient aplastic crisis. $J$. Clin. Invest. 73:224-230.

20. Toretsky J. A., N. T. Shahidi, and J. L. Finlay. 1986. Effects of recombinant human interferon gamma on hematopoietic progenitor cell growth. Exp. Hematol. 14:182-186. 